\title{
The role of probiotics in nosocomial infections
}

\author{
Gian Vincenzo Zuccotti ${ }^{*}$, Fabio Meneghin \\ From XX National Congress of the Italian Society of Neonatology \\ Rome, Italy. 9-11 October 2014
}

\section{Background}

Nosocomial infections are among the leading causes of mortality and morbidity especially in neonatal intensive care unit (NICU) [1]. The intestinal microbiota of the gut is nowadays considered to play an important functional role in the host's health through nutritional, physiological and immunological processes. For these reasons, probiotics may exert actions of prevention and therapy of infectious diseases.

\section{Results}

The mechanisms of action of probiotics are strain specific but can be summarized mainly in three areas: changes of gut ecology, modulation of gut mucosal barrier and regulation of the immune response through interaction with gut-associated immune system [2]. Several studies regarding the supplementation of probiotics in nosocomial infections have been conducted mainly in adult population. Among pediatric studies major findings have been observed in treatment of acute gastroenteritis, primarily caused by Rotavirus [3,4], and in the prevention of antibiotic associated diarrhea (AAD) [5]. Supplementation with probiotics has proven useful even in the treatment of Clostridium difficile disease (CDD), the most common pathogen involved in AAD [6]. Data from meta-analysis and cochrane review on the prevention of necrotizing enterocolitis (NEC) show an overall benefit of probiotic supplementation [7]. The limitations of the above cited studies are mainly related to heterogeneity in terms of strain, dosage and duration of treatment and the lack of studies on extremely low birth weight preterm infants. Data on nosocomial pneumonia and ventilatorassociated pneumonia in neonatal and pediatric age is scanty. In a large randomized, double-blind placebo controlled study, Hojsak et al demonstrated that supplementation with Lactobacillus GG significantly decreased the risk of nosocomial respiratory tract infections [8]. On the other hand, the data from adult studies have been conflicting, with a tendency towards the demonstration of probiotic efficacy in reducing the incidence of ventilatorassociated pneumonia [9]. Meticillin-resistant Staphylococcus aureus is a multidrug-resistant nosocomial pathogen; a recent review of literature [10] showed that many probiotic strains inhibit MRSA growth in vitro. Furthermore, this review describes that there is little published clinical data on the use of probiotics in prophylaxis or treatment of MRSA-mediated infections.

\section{Conclusions}

Due to the significant heterogeneity between the studies in literature it is not possible to draw consistent conclusions on extensive use of probiotics in prevention and treatment of nosocomial infections, except for acute gastroenteritis, AAD, CDD and NEC.

\section{Published: 9 October 2014}

\section{References}

1. Polin RA, Denson S, Brady MT, et al: Epidemiology and Diagnosis of Health Care-Associated Infections in the NICU. Pediatrics 2012, 129: e1104-e1109.

2. Kotzampassi K, Giamarellos-Bourboulis EJ: Probiotics for infectious diseases: more drugs, less dietary supplementation. International Journal of Antimicrobial Agents 2012, 40:288-296.

3. Allen SJ, Martinez EG, Gregorio GV: Probiotics for treating acute infectious diarrhoea (Review). Cochrane Database of Systematic Reviews 2010, , 11: CD003048.

4. Guarino A, Ashkenazi S, Gendrel D, Vecchio AL, Shamir R, Szajewska H: European Society for Pediatric Gastroenterology, Hepatology, and Nutrition/European Society for Pediatric Infectious Diseases EvidenceBased Guidelines for the Management of Acute Gastroenteritis in Children in Europe: Update 2014. JPGN 2014, 59:132-152.

5. McFarland LV: Meta-Analysis of Probiotics for the Prevention of Antibiotic Associated Diarrhea and the Treatment of Clostridium difficile Disease Meta-Analysis of Probiotics for the Prevention of Antibiotic Associated Diarrhea and the Treatment of Clostridium difficile Disease. Am J Gastroenterol 2006, 101:812-822.

6. Goldenberg JZ, Ma SSY, Saxton JD, Martzen MR, Vandvik PO, Thorlund K, Guyatt GH, Johnston BC: Probiotics for the prevention of Clostridium difficile associated diarrhea in adults and children. Cochrane Database of Systematic Reviews 2013, , 5: CD006095. 
7. AlFaleh K, Anabrees J, Bassler D, et al: Probiotics for prevention of necrotizing enterocolitis in preterm infants. Cochrane Database of Systematic Reviews 2011, , 3: CD005496.

8. Hojsak I, Abdovic S, Szajewska H, Milosevic M, Krznaric Z, Kolacek S: Lactobacillus GG in the Prevention of Nosocomial Gastrointestinal and Respiratory Tract Infections. Pediatrics 2010, 125:e1171-e1177.

9. Siempos II, Ntaidou TK, Falagas ME: Impact of the administration of probiotics on the incidence of ventilator-associated pneumonia: A metaanalysis of randomized controlled trials. Crit Care Med 2010, 38:954-962.

10. Sikorska $H$, Smoragiewicz W: Role of probiotics in the prevention and treatment of meticillin-resistant Staphylococcus aureus infections. International Journal of Antimicrobial Agents 2013, 42:475-481.

doi:10.1186/1824-7288-40-S2-A16

Cite this article as: Zuccotti and Meneghin: The role of probiotics in nosocomial infections. Italian Journal of Pediatrics 2014 40(Suppl 2):A16.

\section{Submit your next manuscript to BioMed Central} and take full advantage of:

- Convenient online submission

- Thorough peer review

- No space constraints or color figure charges

- Immediate publication on acceptance

- Inclusion in PubMed, CAS, Scopus and Google Scholar

- Research which is freely available for redistribution

Submit your manuscript at www.biomedcentral.com/submit 